\title{
Malignant Testicular Leydig Cell Tumor
}

National Cancer Institute

\section{Source}

National Cancer Institute. Malignant Testicular Leydig Cell Tumor. NCI Thesaurus. Code C39942.

A Leydig cell tumor characterized by a large size, cellular atypia, high mitotic activity, vascular invasion and necrotic changes. The prognosis is usually poor. 